\title{
ON THE STABILITY OF HOMOMORPHISMS IN QUASI-BANACH ALGEBRAS ASSOCIATED TO THE PEXIDERIZED JENSEN FUNCTIONAL EQUATION
}

\author{
ABBAS NAJATI
}

\begin{abstract}
In this paper, we prove the Hyers-Ulam-Rassias stability of homomorphisms in quasiBanach algebras associated to the Pexiderized Jensen functional equation. This is applied to investigate homomorphisms between quasi-Banach algebras. The concept of Hyers-UlamRassias stability originated from the Th. M. Rassias' stability theorem that appeared in the paper: On the stability of the linear mapping in Banach spaces, Proc. Amer. Math. Soc. 72 (1978), 297-300.
\end{abstract}

Mathematics subject classification (2000): 39B72, 46B03, 47J20.

Key words and phrases: Jensen functional equation, Homomorphism in quasi-Banach algebra, HyersUlam-Rassias stability, $p$-Banach algebra.

\section{REFERENCES}

[1] J. M. Almira, U. Luther, Inverse closedness of approximation algebras, J. Math. Anal. Appl. 314 (2006), 30-44.

[2] C. BAAK, D. BOO AND TH. M. RASSIAS, Generalized additive mapping in Banach modules and isomorphisms between $C^{*}$-algebras, J. Math. Anal. Appl. 314 (2006), 150-161.

[3] B. Belaid, E. ElHOUCIEN AND TH. M. RASSIAS,On the Hyers-Ulam stability of approximately Pexider mappings, Mathematical Inequalities and Applications, (to appear).

[4] Y. Benyamini, J. Lindenstrauss, Geometric Nonlinear Functional Analysis, vol. 1, Colloq. Publ., vol. 48, Amer. Math.Soc., Providence, RI, 2000.

[5] P. CzERWIK, Functional Equations and Inequalities in Several Variables, World Scientific Publishing Company, New Jersey, Hong Kong, Singapore and London, 2002.

[6] S. CZERWIK, Stability of Functional Equations of Ulam-Hyers-Rassias Type, Hadronic Press, Inc., Palm Harbor, Florida, 2003.

[7] Z. GAJDA, On stability of additive mappings, Internat. J. Math. Sci. 14 (1991), 431-434

[8] P. GĂVRUTA, A generalization of the Hyers-Ulam-Rassias stability of approximately additive mappings, J. Math. Anal. Appl. 184 (1994), 431-436.

[9] D. H. HYERS, On the stability of the linear functional equation, Proc. Nat. Acad. Sci. U.S.A. 27 (1941), $222-224$

[10] D. H. HyeRs AND TH. M. RASSIAS, Approximate homomorphisms, Aequationes Mathematicae 44(1992), 125-153.

[11] D. H. Hyers, G. IsAC AND Th. M. RAssias, Stability of Functional Equations in Several Variables, Birkhäuser, Basel, 1998.

[12] D. H. HYERS, G. IsAC AND TH. M. RASSIAS, On the asymptoticity aspect of Hyers-Ulam stability of mappings, Proc. Amer. Math. Soc. 126 (1998), 425-430.

[13] G. ISAC AND TH. M. RASSIAS, Stability of $\psi$-additive mappings : Applications to nonlinear analysis, Internat. J. Math. Math. Sci. 19 (1996), 219-228.

[14] B. E. JoHnSON, Approximately multiplicative functionals, J. London Math. Soc., 34 (1986), $489-510$.

[15] S. Jung, On the Hyers-Ulam-Rassias stability of approximately additive mappings, J. Math. Anal. Appl. 204 (1996), 221-226. 
[16] S.-M. JuNG, Hyers-Ulam-Rassias Stability of Functional Equations in Mathematical Analysis, Hadronic Press, Inc., Palm Harbor, Florida, 2001.

[17] Y. H. LEE AND K. W. JUN, A note on the Hyers-Ulam-Rassias stability of Pexider equation, J. Korean Math. Soc. 37 (2000), 111-124.

[18] A. NAJATI AND C. PARK, Hyers-Ulam-Rassias stability of homomorphisms in quasi-Banach algebras associated to the Pexiderized Cauchy functional equation, J. Math. Anal. Appl. 335 (2007), 763-778.

[19] C. PARK, On the stability of the linear mapping in Banach modules, J. Math. Anal. Appl. 275 (2002), 711-720.

[20] C. PARK, A generalized Jensen's mapping and linear mappings between Banach modules, Bull. Braz. Math. Soc. 36 (2005), 333-362.

[21] C. PARK, Hyers-Ulam-Rassias stability of homomorphisms in quasi-Banach algebras, Bull. Sci. Math. (to appear).

[22] C. PARK, H. ChU, W. PARK AND H. WEE, On homomorphisms between $C^{*}$-algebras and linear derivations on $C^{*}$-algebras, Czecho. Math. J. 55 (2005), 1055-1065.

[23] J. M. RASSIAS, On approximation of approximately linear mappings by linear mappings, Bull. Sci. Math. 108 (1984), 445-446.

[24] J.M. RASSIAS, Solution of a problem of Ulam, J. Approx. Theory 57 (1989), 268-273.

[25] TH. M. RASSIAS, On the stability of the linear mapping in Banach spaces, Proc. Amer. Math. Soc. 72 (1978), 297-300.

[26] TH. M. RASSIAS, The problem of S.M. Ulam for approximately multiplicative mappings, J. Math. Anal. Appl. 246 (2000), 352-378.

[27] TH. M. RASSIAS, Problem 16; 2, Report of the $27^{\text {th }}$ International Symp. on Functional Equations, Aequationes Math. 39 (1990), 292-293; 309.

[28] TH. M. RASSIAS, On the stability of functional equations in Banach spaces, J. Math. Anal. Appl. 251 (2000), 264-284.

[29] TH. M. RASSIAS, On the stability of functional equations and a problem of Ulam, Acta Appl. Math. 62 (2000), 23-130.

[30] TH. M. Rassias, Functional Equations, Inequalities and Applications, Kluwer Academic Publishers, Dordrecht, Boston and London, 2003.

[31] TH. M. RASSIAS AND P. ŠEMRL, On the behavior of mappings which do not satisfy Hyers-Ulam stability, Proc. Amer. Math. Soc. 114 (1992), 989-993.

[32] S. RolewICZ, Metric Linear Spaces, PWN-Polish Sci. Publ., Warszawa, Reidel, Dordrecht, 1984.

[33] F. SkOF, Proprietà locali e approssimazione di operatori, Rend. Sem. Mat. Fis. Milano 53 (1983), $113-129$.

[34] S. M. Ulam, A Collection of the Mathematical Problems, Interscience Publ. New York, 1960. 